\title{
Prunus Yedoensis Inhibits the Inflammatory Chemokines, MDC and TARC, by Regulating the STAT1-Signaling Pathway in IFN- $\gamma$-stimulated HaCaT Human Keratinocytes
}

\author{
Gyeoung-Jin KANG ${ }^{1}$, Hye-Ja LeE ${ }^{1}$, Weon-Jong Yoon ${ }^{1}$, Eun-Jin YANG ${ }^{1}$, Sun-Son PARK ${ }^{1}$, \\ Hee-Kyoung KANG ${ }^{1}$, Myung-Hwan PARK ${ }^{2}$, and Eun-Sook Yoo ${ }^{1}$ \\ ${ }^{1}$ Department of pharmacology, School of Medicine, Cheju National University, Jejudaehakno 66, Jeju 690-756, Republic of Korea. \\ ${ }^{2}$ GyeongGi Bio-Center, lui-dong, Yeongtong-gu, Suwon, Gyeonggi 443-270, Republic of Korea
}

(Received September 10, 2008; Revised November 5, 2008; Accepted November 10, 2008)

\begin{abstract}
Atopic dermatitis (AD) is an inflammatory skin disease commonly characterized by infiltration of inflammatory cells into skin lesions. Keratinocytes produce many chemokines that are involved in the pathogenesis of skin disorders. In particular, macrophage-derived chemokine (MDC/CCL22) and thymus and activationregulated chemokine (TARC/CCL17) are Th2-type cytokines. Serum MDC and TARC levels are increased in AD patients. In this study, we investigated the anti-inflammatory effect and mechanism of action of the active fraction from Prunus yedoensis bark. We evaluated their inhibitory effects on the AD-like inflammatory markers (MDC and TARC) and JAK-STAT pathway (STAT1) in HaCaT keratinocytes. The EtOAc fraction of the crude extract $(80 \% \mathrm{EtOH})$ and the E5 sub-fraction potently inhibited the induction of MDC and TARC mRNA and protein at $50 \mu \mathrm{g} / \mathrm{mL}$ in HaCaT cells. In addition, the E5 sub-fraction inhibited the phosphorylation of STAT1 protein associated with IFN- $\gamma$ signaling transduction in a dose-dependent manner. Thus, $P$. yedoensis may have antiatopic activity by suppressing the inflammatory chemokines (MDC and TARC).
\end{abstract}

Keywords: Prunus yedoensis, Atopic dermatitis (AD), MDC (CCL22), TARC (CCL17), JAK-STAT pathway, $\mathrm{HaCaT}$ keratinocytes

\section{INTRODUCTION}

Atopic dermatitis (AD) is a chronic, relapsing inflammatory skin disease caused by complex interactions between genetic and environmental factors. AD is characterized by the infiltration of Th2-type cells, eosinophils, mast cells, and macrophages into lesioned skin. Infiltration of inflammatory cells into tissues is regulated by various chemokines. Lesioned skin also contains high levels chemokines, including MDC and TARC (Bonncchi et al., 1998; Luster, 2001; Hijnen et al., 2004; Baumer et al., 2004).

Chemokines attract leukocytes to sites of infection and inflammation. In particular, macrophage-derived chemokine (MDC/CCL22) and thymus- and activation-regulated chemokine (TARC/CCL17), called Th2 chemokines, play

\footnotetext{
${ }^{*}$ Corresponding author

Tel: +82-64-754-3847, Fax: +82-64-702-2687

E-mail: eunsyoo@cheju.ac.kr
}

important roles in the recruitment of Th2-type cells into AD lesions (Saeki et al., 2006; Nakazato et al., 2008). MDC is a CC chemokine that serves as a potent chemoattractant for monocytes, monocyte-derived dendritic cells (DCs), and natural killer (NK) cells (Godiska et al., 1997; Bonncchi et al., 1998). TARC is a CC chemokine produced by monocyte-derived dendritic cells, endothelial cells, and keratinocytes. The ligands for CCR4 are MDC and TARC, whose levels in the blood of AD patients correlate with disease activity (Fujisawa et al., 2002; Kakinuma et al., 2002; Shinada et al., 2004; Rozyk et al., 2005). TARC is highly expressed in keratinocytes and the basal epidermis of NC/Nga mice exhibiting AD-like lesions (Vestergaard et al., 1999; Horikawa et al., 2002; Xiao et al., 2003; Jakubzick et al., 2004).

Several cell types respond rapidly following stimulation with inflammatory cytokines via various signaling pathways, such as the Janus kinase-signal transducer and activator of transcription (JAK-STAT) signaling pathway (Esche et al., 2004). IFN- $\gamma$ activates the JAK-STAT path- 
way, STAT, ERK, and p38 MAP kinases (Komine et al., 2005). IFN- $\gamma$ and TNF- $\alpha$ activate Jak1/Jak2 and Jak1/ Tyk2, respectively. Also, STAT proteins are activated by various ligands, such as IFN- $\gamma$, IL-6, and IL-4 (Strobl et al., 2001; Han et al., 2002; Ivashkiv and $\mathrm{Hu}, 2004)$. In brief, after ligand binding to the receptor subunits, the Jaks trans-phosphorylate each other and then phosphorylate critical tyrosine residues within the intracellular domains of the receptor subunits. Then, STAT proteins binds phosphorylated residues on the intracellular domain of activated receptor and are subsequently phosphorylated by the Jaks. Phosphorylated STAT proteins compose homo- and hetero-dimers with other STAT proteins and translocate to the nucleus, where they bind specific DNA sequences within the promoter regions of IFN-stimulated genes (ISGs) (Best et al., 2005).

Prunus yedoensis barks are used for pertussis, irritable and persistent coughs from bronchitis, coughs due to increased irritability of the respiratory mucosa, and nervous dyspepsia. Particularly, the barks are used for cough, nervous dyspepsia, detoxification, and relaxation in traditional Korea medicine. Also, the barks have immunosuppressant activity and anti-allergic effects (Han, 1978; Park et al., 1998). However, their mechanism of action has not been reported.

Consequently, we aimed to find the active fraction using activity-guided fractionation and to clarify the mechanism of action of $P$. yedoensis barks. In this study, we first investigated the anti-inflammatory effects of solvent fractions from $P$. yedoensis barks through inhibition of AD-mediating inflammatory markers (MDC and TARC). Furthermore, we explored the mechanism of action via the JAK-STAT pathway (STAT1 and PSTAT1) of the E5 sub-fraction from $P$. yedoensis barks in IFN- $\gamma$-stimulated $\mathrm{HaCaT}$ human keratinocytes.

\section{MATERIALS AND METHODS}

\section{Reagents}

HaCaT human keratinocytes were provided by Prof. Moon Je Cho (Department of Biochemistry, Cheju National University, Korea). Human interferon- $\gamma$ (hIFN- $\gamma$, recombinant $E$. coll) was obtained from Roche (Korea). Fetal bovine serum (FBS) and Dulbecco's modified Eagle's medium (DMEM) were obtained from GIBCO (Grand Island, NY). MDC/CCL22 and TARC/CCL17 primers were obtained from Bioneer (Korea). $\beta$-actin primers were purchased from Bionex (Korea). Mouse anti-STAT1 and rabbit anti-pSTAT1 antibodies were obtained from BD Biosciences (San Jose, CA) and Cell Signaling Tech- nology (Beverly, MA), respectively. Mouse anti- $\beta$-actin antibody was obtained from Sigma (St. Louis, MO). Horseradish peroxidase (HRP)-conjugated anti-mouse and ant-rabbit secondary antibodies were purchased from Vector (Southfield, MI) and Cell Signaling Technology (Beverly, MA), respectively. Bovine serum albumin (BSA) was purchased from Amresco (Solon, $\mathrm{OH}$ ). Human MDC and TARC enzyme-linked immunosorbent assay (ELISA) kits were obtained from R\&D Systems (St. Louis, MO). All other reagents were reagent grade.

\section{Solvent extract and isolation of active ingredients}

The powder $(60 \mathrm{~g})$ of $P$. yedoensis bark was extracted with $6 \mathrm{~L}$ ethanol twice for $3 \mathrm{hr}$ and filtered through filter paper. The filtrate was evaporated to dryness in a Rotavapor (PR-T, $8.6 \mathrm{~g}$ ). The ethanol extract $(3 \mathrm{~g})$ was successively extracted using ethyl acetate, n-butanol, and water. The yield of extraction by ethyl acetate (PR-E), nbutanol (PR-B), and water (PR-W) was $0.92 \mathrm{~g}, 1.18 \mathrm{~g}$, and $0.9 \mathrm{~g}$, respectively. Also, PR-E $(5 \mathrm{~g})$, which had inhibitory effects, was separated on a Si gel column and subfractions (PR-E1, -E2, -E3, -E4, -E5) were obtained. The standard material of $P$. yedoensis was deposited in the laboratory of pharmacology, school of medicine, cheju national university under the standard number CNUPHARM-50608PR.

\section{Cell culture}

HaCaT human keratinocytes were cultured in DMEM supplemented with $10 \%$ FBS and $100 \mathrm{U} / \mathrm{mL}$ penicillinstreptomycin in a humidified $\mathrm{CO}_{2}$ incubator.

\section{LDH assay}

The levels of lactate dehydrogenase (LDH) in the extracellular space were determined using a Cytotox $96 \AA$ Non-Radioactive Cytotoxicity Assay kit (Promega, Madison, $\mathrm{WI}$ ). A sample of $50 \mu \mathrm{L}$ was taken from the culture medium and mixed with an equal volume of the substrate solution [0.054 M L-(+)-lactic acid, $1.3 \mathrm{mM} \beta$ $\mathrm{NAD}+, 0.66 \mathrm{mM}$ INT and $0.28 \mathrm{mM}$ phenazine methosulfate dissolved in $0.2 \mathrm{M}$ Tris ( $\mathrm{pH}$ 8.2)]. After 30 min shaking at room temperature, the enzymatic reaction was stopped by adding $50 \mu \mathrm{L}$ of $1 \mathrm{M}$ acetic acid. The absorbances of the samples were measured at $490 \mathrm{~nm}$ to detect the presence of reduced INT, and 9\% Triton X-100 was used to determine the maximal LDH content of the cells by allowing complete lysis.

\section{Extraction of total RNA and RT-PCR}

Total RNA from hIFN- $\gamma$-treated HaCaT cells was iso- 
Table I. The sequence of primers and fragment sizes of the investigated genes in RT-PCR analysis

\begin{tabular}{cccc}
\hline Gene & \multicolumn{1}{c}{ Primer sequences } & Fragment size (bp) \\
\hline \multirow{2}{*}{ MDC } & Sense & 5'-GCATGGCTCGCCTACAGACT-3' & 497 \\
& Antisense & 5'-GCAGGGAGGGAGGCAGAGGA-3' & 351 \\
\multirow{2}{*}{ TARC } & Sense & 5'-ATGGCCCCACTGAAGATGCT-3' & \\
& Antisense & 5'-TGAACACCAACGGTGGAGGT-3' & 588 \\
\multirow{2}{*}{ 3-actin } & Sense & 5'-ATGGGTCAGAAGGATT-CCTATG-3' & \\
& Antisense & 5'-CAGCTCGTAGCTC-TTCTCCA-3'
\end{tabular}

lated using the easy-Blue ${ }^{T M}$ Total RNA Extraction kit (iNtRON Biotechnology, Korea) according to the manufacturer's instructions. Total RNA was stored at $-70^{\circ} \mathrm{C}$ until use.

Reverse transcription was performed using a FirstStandard cDNA Synthesis kit (Promega). Briefly, total RNA $(1 \mu \mathrm{g})$ was incubated with oligo(dT) $)_{18}$ primer at $70^{\circ} \mathrm{C}$ for $5 \mathrm{~min}$ and cooled on ice for $5 \mathrm{~min}$. After addition of the RT premix, reactions were incubated at $37^{\circ} \mathrm{C}$ for $60 \mathrm{~min}$. The reactions were terminated at $70^{\circ} \mathrm{C}$ for 15 min. The PCR reaction was conducted using $\mathrm{i}-\mathrm{Taq}^{\mathrm{TM}}$ DNA polymerase (iNtRON Biotechnology) with the appropriate sense and antisense primers for MDC, TARC, and $\beta$-actin. Primers used in this experiment are shown in Table 1.

PCR was performed in a Peltier Thermal Cycler (PTC100, MJ research, Reno, NV) for 32 cycles (30 cycles for $\beta$-actin). Each cycle included denaturing at $94^{\circ} \mathrm{C}$ for 30 $\mathrm{sec}$, annealing at $55-60^{\circ} \mathrm{C}$ for $30 \mathrm{sec}$, and extending at $72^{\circ} \mathrm{C}$ for $2 \mathrm{~min}$. A final extension at $72^{\circ} \mathrm{C}$ for $10 \mathrm{~min}$ was performed at the end of the cycles. The reaction products were visualized by electrophoresis on a $1.2 \%$ agarose gel (Promega) and UV light illumination after staining with ethidium bromide. The relative intensity was analyzed using Quantity One software version 4.2.1.

\section{ELISA}

Concentrations of MDC and TARC in the supernatant were measured with an ELISA kit according to the manufacturer's instructions using an ELISA reader, EL800 (Bio-Tek Instruments, INC., Winooski, VT). Briefly, samples were added to each well and incubated for $2 \mathrm{hr}$ at room temperature (RT). After washing, anti-MDC and anti-TARC antibodies conjugated to HRP were added to each well. The plates were incubated for $1 \mathrm{hr}$ at room temperature. After washing, a substrate solution (including tetramethylbenzidine) was added and incubated for $30 \mathrm{~min}$. The optical density of each well was determined using an ELISA reader. The minimum detectable doses of MDC and TARC were typically less than 62.5 and 7 $\mathrm{pg} / \mathrm{mL}$, respectively.

\section{Western blot analysis}

HaCaT cells were pre-incubated for $18 \mathrm{hr}$ and then stimulated with IFN- $\gamma(10 \mathrm{ng} / \mathrm{mL})$ in the presence to testing materials for $24 \mathrm{hr}$. After incubation, the cells were collected and washed twice with cold PBS. The cells were disrupted in lysis buffer $[50 \mathrm{mM}$ Tris- $\mathrm{HCl}(\mathrm{pH} 7.5)$, $150 \mathrm{mM} \mathrm{NaCl}, 1 \%$ Nonident P-40, 2 mM EDTA, $1 \mathrm{mM}$ EGTA, $1 \mathrm{mM} \mathrm{NaVO}$, $10 \mathrm{mM} \mathrm{NaF}, 1 \mathrm{mM}$ DTT, $1 \mathrm{mM}$ phenylmethylsulfonyl fluoride, $25 \mu \mathrm{g} / \mathrm{mL}$ leupeptin] and kept on ice for $30 \mathrm{~min}$. The cell lysates were centrifuged at $15,000 \mathrm{rpm}$ for $15 \mathrm{~min}$ at $4^{\circ} \mathrm{C}$, and the supernatants were used for Western blotting. Total protein concentration of each samples were quantified by the Bio-Rad assay method (Bio-Rad, Hercules, CA). Extracts containing 30 $\mu \mathrm{g}$ of protein were separated on an $8 \%$ sodium dodecylsulfate (SDS) polyacrylamide gel and transferred onto a polyvinylidene fluoride (PVDF) membrane. The membrane was blocked with blocking buffer ( $5 \%$ skim milk in TTBS) for $2 \mathrm{hr}$ at room temperature, followed by incubation with mouse anti-STAT1 (1:1000), mouse anti-pSTAT1 (1:1000) and mouse anti- $\beta$-actin (1:2500) antibodies overnight at $4^{\circ} \mathrm{C}$. All antibodies were diluted in $1 \%$ BSA in TTBS buffer. After washing, the membrane was incubated with horseradish peroxidase (HRP)-conjugated anti-mouse IgG and anti-rabbit lgG diluted 1:5000 for $1 \mathrm{hr}$ at RT. The result was visualized with a Western blot detection system (iNtRON Biotechnology) according to the manufacture's instructions.

\section{Statistical analysis}

Quantity One version 4.2.1 and Image-Pro plus version 4.5 were used to transform images into numerical values. Student's t-test and two-way analysis of variance were used to determine the statistical significance of differences between values for the experimental and control groups. Data represent the mean \pm standard error. 


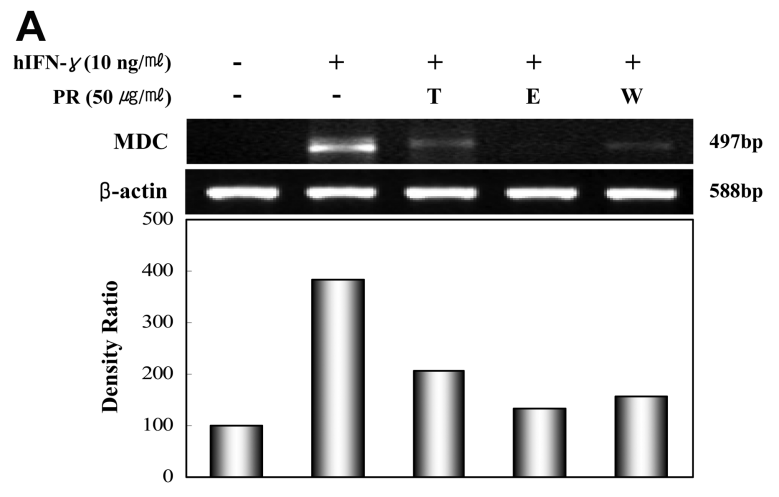

B

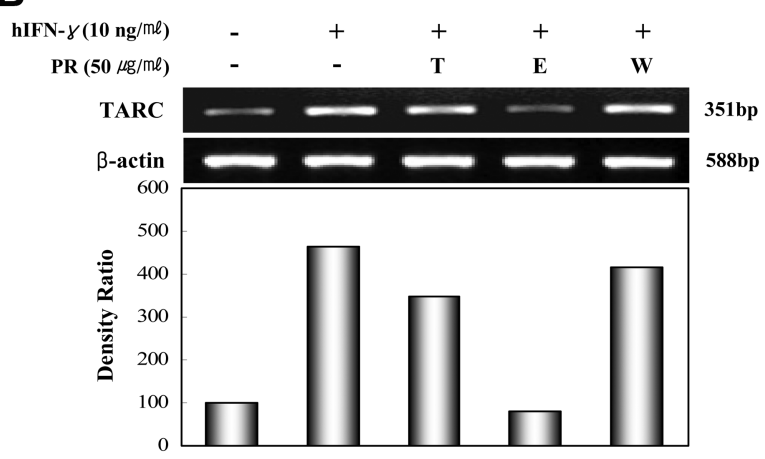

C

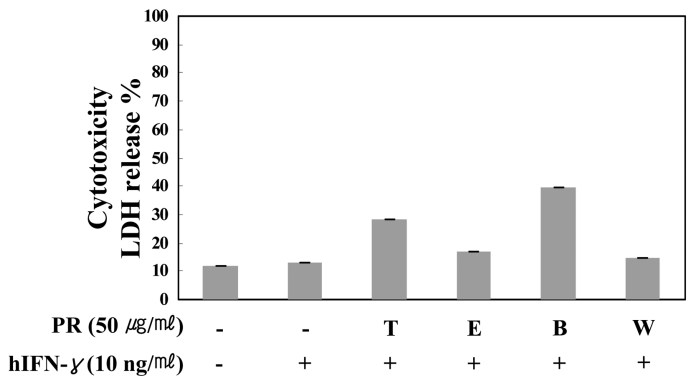

Fig. 1. Effect of solvent fractions of $P$. yedoensis on MDC and TARC mRNA expression (A, B) and $L D H$ release (C) in HaCaT human keratinocytes. A, B) Cells $\left(5.0 \times 10^{5}\right.$ cells $\left./ \mathrm{mL}\right)$ were pre-incubated for $18 \mathrm{hr}$, and the mRNA expression levels of MDC and TARC were determined from the $24 \mathrm{hr}$ culture of cells stimulated by hIFN- $\gamma(10 \mathrm{ng} / \mathrm{mL})$ in the presence of $P$. yedoensis $(50 \mu \mathrm{g} / \mathrm{mL})$. C) Cells $\left(2.0 \times 10^{5}\right.$ cells/well) were preincubated for $18 \mathrm{hr}$, and LDH release was measured after 24 hr stimulation with hIFN- $\gamma(10 \mathrm{ng} / \mathrm{mL})$ in the presence of $P$. yedoensis $(50 \mu \mathrm{g} / \mathrm{mL})$. P. yedoensis fractions were co-treated with IFN- $\gamma$. T: EtOH fraction, E: EtOAc fraction, $\mathrm{B}: \mathrm{BuOH}$ fraction, $\mathrm{W}: \mathrm{H}_{2} \mathrm{O}$ fraction.

\section{RESULTS}

EtOAc fraction of $P$. yedoensis bark inhibits expression of MDC and TARC mRNAs

We measured the ability of fractions of $P$. yedoensis
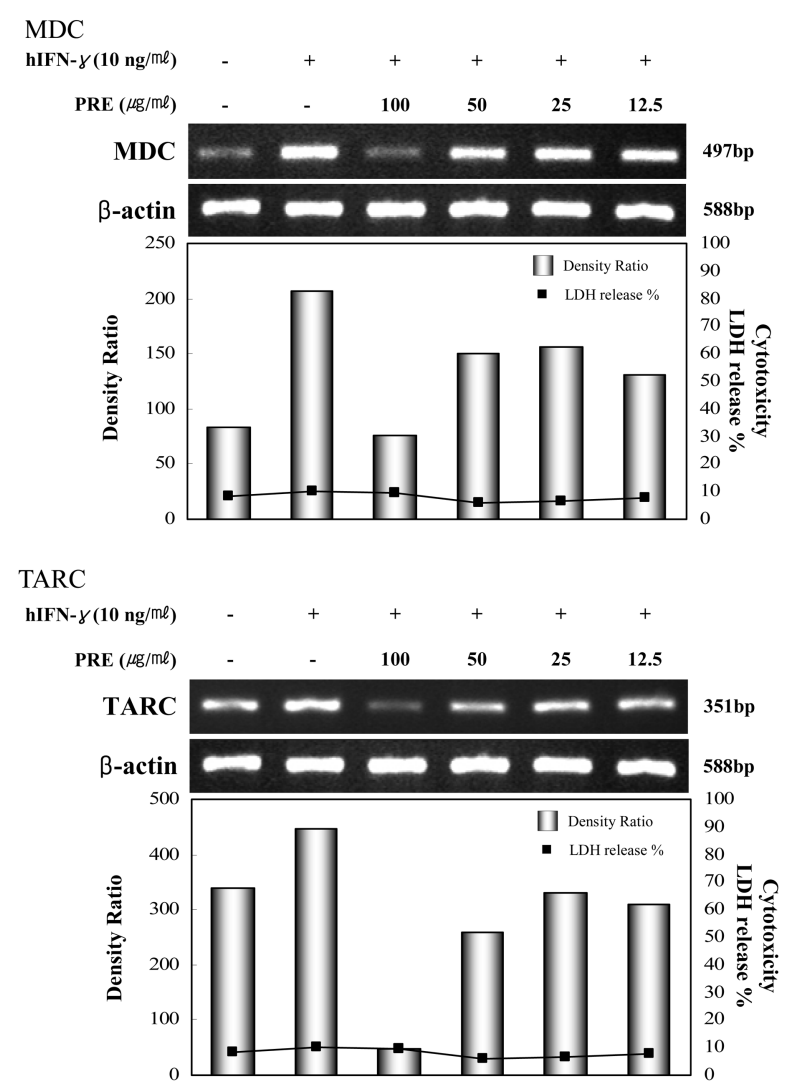

Fig. 2. Effects of the EtOAc fraction of $P$. yedoensis bark on MDC and TARC mRNA expression in HaCaT human keratinocytes stimulated with IFN- $\gamma$. Cells $\left(5.0 \times 10^{5}\right.$ cells $\left./ \mathrm{mL}\right)$ were pre-incubated for $18 \mathrm{hr}$, and the mRNA expression levels of MDC and TARC were determined from the $24 \mathrm{hr}$ culture of cells stimulated with hIFN- $\gamma(10 \mathrm{ng} / \mathrm{mL})$ in the presence of $P$. yedoensis $(100,50,25,12.5 \mu \mathrm{g} / \mathrm{mL})$. P. yedoensis EtOAc fraction was co-treated with IFN- $\gamma$.

barks to inhibit MDC and TARC mRNA induction using RT-PCR. Fraction cytotoxicity was then measured using $\mathrm{LDH}$ assays. The EtOAc fraction from $P$. yedoensis bark showed the highest inhibition on the expression of MDC and TARC mRNA in HaCaT cells stimulated with IFN- $\gamma$ (Fig. 1A, B). Solvent fractions did not show cytotoxicity against $\mathrm{HaCaT}$ cells (Fig. 1C). However, the $\mathrm{BuOH}$ fraction was slightly cytotoxic $(39.8 \%)$ at $50 \mu \mathrm{g} / \mathrm{mL}$. The EtOAc fraction dose-dependently inhibited MDC and TARC mRNA induction (Fig. 2).

EtOAc sub-fraction E5 from $P$. yedoensis bark inhibits the mRNA expression and protein production of MDC and TARC

We next determined whether the EtOAc sub-fractions could affect MDC and TARC mRNA and protein levels 
A

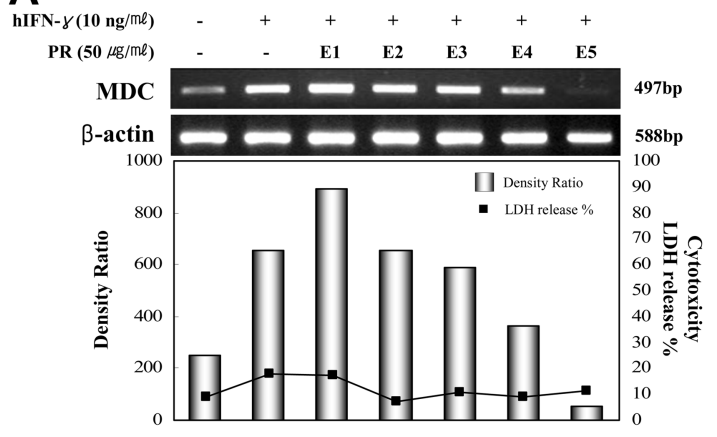

B

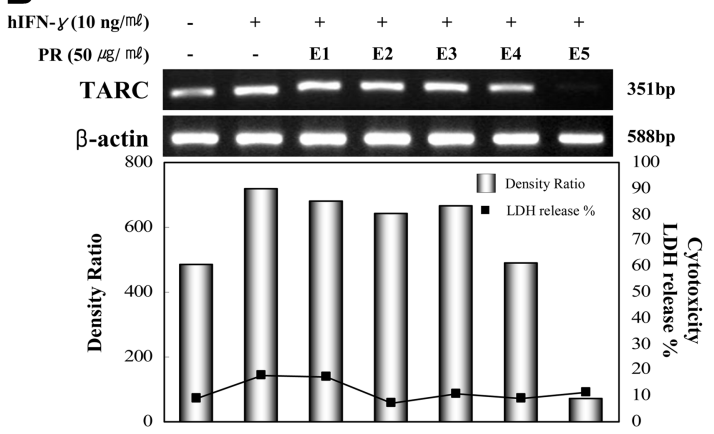

C

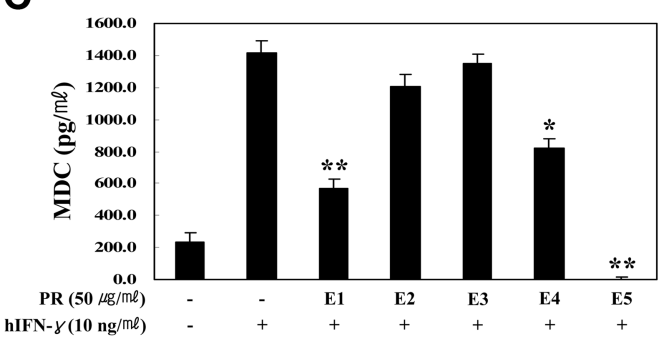

D

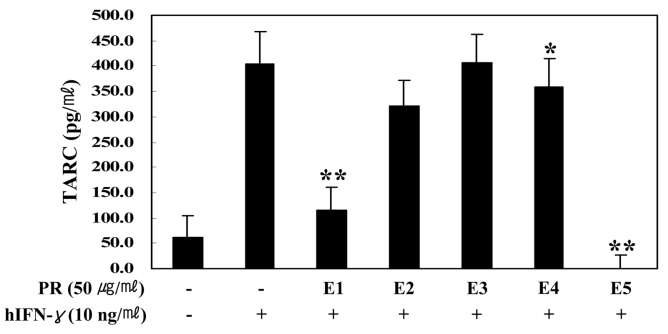

Fig. 3. Effects of the EtOAc sub-fractions of $P$. yedoensis bark on the mRNA and protein levels of MDC and TARC in HaCaT human keratinocytes stimulated with IFN- $\gamma$. Cells were pre-incubated for $18 \mathrm{hr}, \mathrm{A}, \mathrm{B}$ ) the mRNA expression levels of MDC and TARC were determined from the $24 \mathrm{hr}$ culture of cells stimulated with hIFN- $\gamma(10 \mathrm{ng} / \mathrm{mL})$ in the presence of $P$. yedoensis ( $50 \mu \mathrm{g} / \mathrm{mL}$ ), C, D) the production of proteins (MDC and TARC) was measured by ELISA of the culture supernatants of HaCaT cells stimulated with hIFN- $\gamma(10 \mathrm{ng} / \mathrm{mL})$ in the presence of $P$. yedoensis $(50 \mu \mathrm{g} / \mathrm{mL})$. $P$. yedoensis EtOAc subfractions were co-treated with IFN- $\gamma * p<0.05 ; * * p<0.01$.
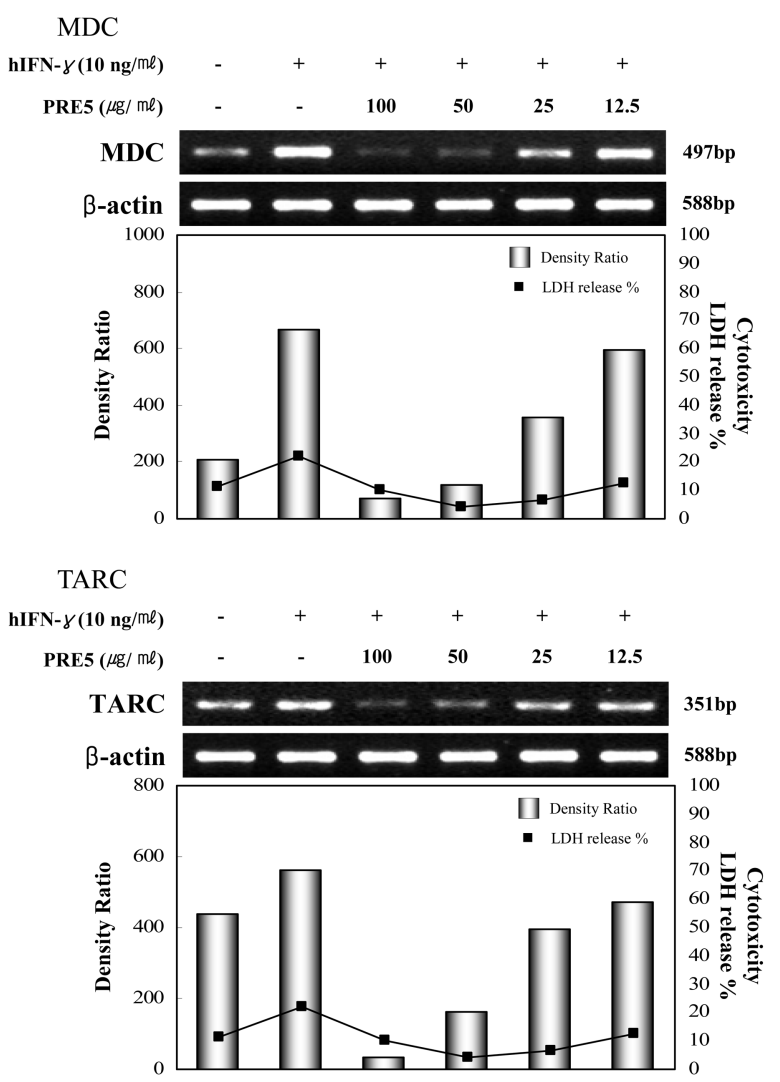

Fig. 4. Effects of the EtOAc sub-fraction (E5) of $P$. yedoensis bark on MDC and TARC mRNA expression levels in HaCaT human keratinocytes stimulated with IFN- $\gamma$. Cells $\left(5.0 \times 10^{5}\right.$ cells $\left./ \mathrm{mL}\right)$ were pre-incubated for $18 \mathrm{hr}$, and the mRNA expression levels of MDC and TARC were determined from the $24 \mathrm{hr}$ culture of cells stimulated with hIFN- $\gamma(10 \mathrm{ng} /$ $\mathrm{mL})$ in the presence of $P$. yedoensis $(100,50,25,12.5 \mu \mathrm{g} / \mathrm{mL})$. $P$. yedoensis E5 sub-fraction was co-treated with IFN- $\gamma$.

using RT-PCR and ELISA, respectively. Of the EtOAc fractions of $P$. yedoensis, the E5 sub-fraction clearly exhibited inhibitory effects on mRNA levels of MDC and TARC (Figure 3A, B). Moreover, in supernatants from cultured $\mathrm{HaCaT}$ cells stimulated with hIFN- $\gamma$, treatment with the E5 sub-fraction inhibited the induction of MDC and TARC protein, as did the E1 fraction (Fig. 3C, D). The E5 sub-fraction dose-dependently inhibited MDC and TARC mRNA expression in $\mathrm{HaCaT}$ cells stimulated with IFN- $\gamma$ (Figure 4).

The EtOAc sub-fraction (E5) of $P$. yedoensis bark inhibits IFN- $\gamma$-induced phosphorylation and expressions of STAT1 protein

We next examined the effects of the E5 sub-fraction on the levels of STAT1 protein in the JAK-STAT signaling 


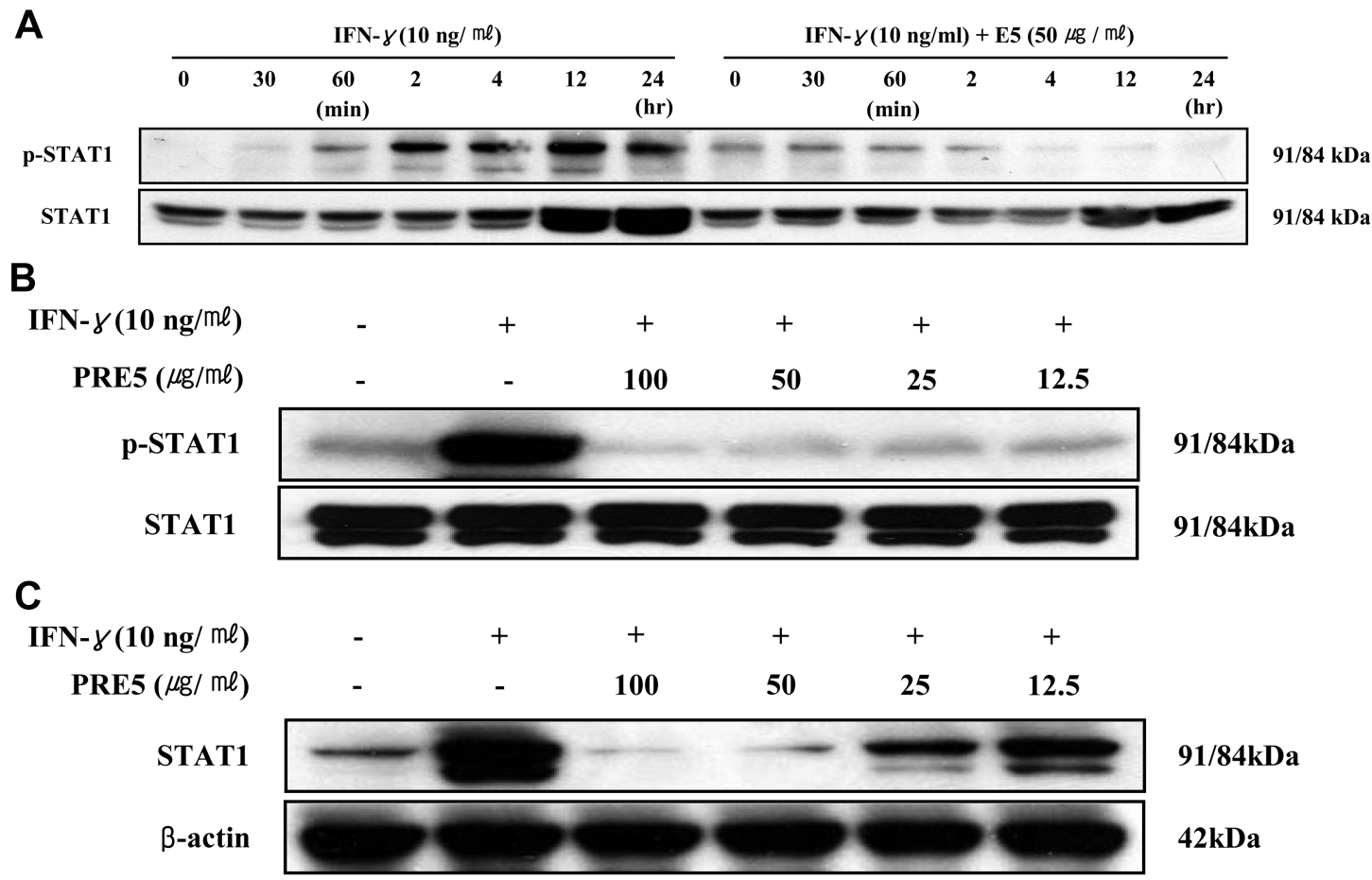

Fig. 5. Effects of the EtOAc sub-fraction (E5) of $P$. yedoensis on STAT1 protein levels and STAT1 phosphorylation in IFN- $\gamma$ stimulated HaCaT human keratinocyte. (A) time course, (B) phosphorylation of STAT1 protein, (C) levels of STAT1 protein. HaCaT cells $\left(5.0 \times 10^{5}\right.$ cells $\left./ \mathrm{mL}\right)$ were pre-incubated for $18 \mathrm{hr}$ and $(A)$ pre-treated with the E5 sub-fraction $(50 \mu \mathrm{g} / \mathrm{mL})$ for $30 \mathrm{~min}$ before addition of IFN- $\gamma$. Subsequently, the cells were stimulated with $\mathrm{hIFN}-\gamma(10 \mathrm{ng} / \mathrm{mL})$ for the indicated times, (B) the cells were stimulated with hIFN- $\gamma(10 \mathrm{ng} / \mathrm{mL})$ in the presence of $P$. yedoensis $(100,50,25,12.5 \mu \mathrm{g} / \mathrm{mL})$ for $2 \mathrm{hr}$, or (C) the cells were stimulated with hIFN- $\gamma(10 \mathrm{ng} / \mathrm{mL})$ in the presence of E5 $(100,50,25,12.5 \mu \mathrm{g} / \mathrm{mL})$ for $24 \mathrm{hr}$. $P$. yedoensis E5 sub-fraction was co-treated with IFN- $\gamma$.

pathway, which is associated with IFN- $\gamma$ signal transduction, in $\mathrm{HaCaT}$ cells stimulated with IFN- $\gamma$ using Western

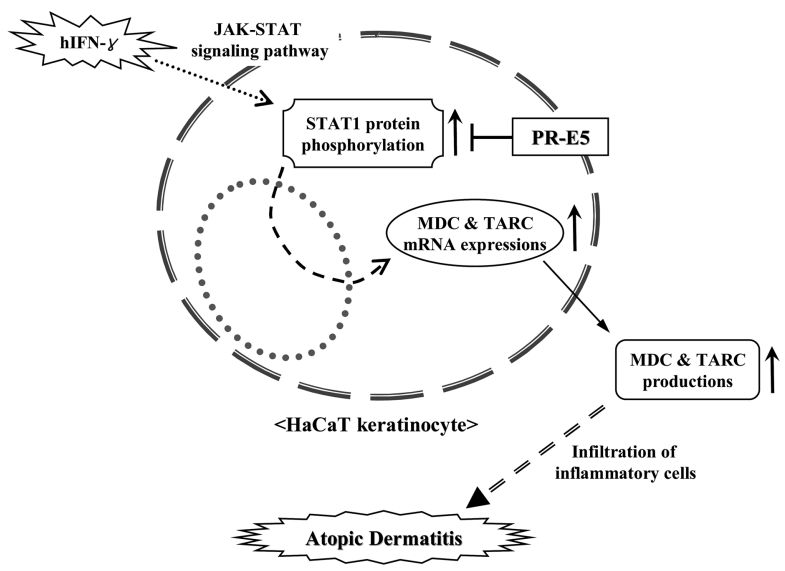

Fig. 6. Possible mechanisms by which PR-E5 inhibits the inflammatory chemokines, MDC and TARC, associated with AD in IFN- $\gamma$-stimulated HaCaT human keratinocyte. blotting. STAT1 protein was expressed in HaCaT cells stimulated by IFN- $\gamma(10 \mathrm{ng} / \mathrm{mL})$, and the E5 sub-fraction inhibited IFN- $\gamma$-mediated activation of STAT1 (data not shown).

Next, we examined whether the E5 sub-fraction inhibited phosphorylation of STAT1 in IFN- $\gamma$ stimulated HaCaT cells. IFN- $\gamma$-stimulation induced phosphorylation of STAT1 in $\mathrm{HaCaT}$ cells in a time-dependent manner, and treatment with the E5 sub-fraction inhibited this STAT1 phosphorylation (Figure 5A). IFN- $\gamma$ induced STAT1 phosphorylation after $2 \mathrm{hr}$ and STAT1 protein induction after $24 \mathrm{hr}$, the E5 sub-fraction dosedependently inhibited the IFN- $\gamma$-induced increase in STAT1 phosphorylation and STAT1 protein levels (Fig. 5B, C).

\section{DISCUSSION}

Prunus yedoensis, a native plant of the Jeju Island in Korea, grows in temperate regions of the northern hemisphere and has been used as a folk remedy for beriberi, dropsy, and mastitis. In particular, the trunk and bark are 
used to treat cough, urticaria, and indigestion in traditional Korea medicine (Jung et al., 2004). Also, the bark has anti-allergic and anti-oxidant activities and improves the immune system (Han et al., 1978; Park et al., 1998). However, the anti-atopic activity and the mechanism of action of fractions isolated from Prunus yedoensis have not been reported. Therefore, we investigated the antiatopic activity of $P$. yedoensis bark and confirmed that the EtOAc fraction and the E5 sub-fraction from $P$. yedoensis inhibited inflammatory chemokines, MDC and TARC, related with atopic dermatitis (Fig.1-4).

Atopic dermatitis $(A D)$ is a chronic inflammatory skin disease with a relapsing course. The pathogenesis of $A D$ is mediated by CD4+ T lymphocytes that produce a Th2 cytokine profile. MDC and TARC are Th2 chemokines that specifically act on the chemokine receptor, CCR4, to attract Th2 cells into sites of allergic inflammation. Serum levels of MDC and TARC are significantly increased with $A D$ patient and $A D$-like murine models (Vestergaard et al., 1999; Horikawa et al., 2002; Xiao et al., 2003; Jakubzick et al., 2004). Various inflammatory factors, as well as MDC and TARC, have been correlated with $A D$ immunopathology, including interferon (IFN)- $\gamma$ and tumour necrosis factor (TNF)- $\alpha$ (Bordignon et al., 2005). Also, in vitro, it has been demonstrated that human skin keratinocytes and fibroblasts are potent producers of inflammatory chemokines by proinflammatory cytokines such as IFN- $\gamma$, TNF- $\alpha$, IL-4, etc. (Yu et al., 2002). Although AD is widely known Th2 type, various clinical studies suggested that Th1 cytokines play a role in the development of $A D$ lesion and that expansion signals for IFN- $\gamma$ are enhanced in the majority of atopic skin lesion (Grewe et al., 1994; Shimada et al., 2004).

Therefore, we investigated the inhibitory activity of $P$. yedoensis bark on the inflammatory chemokines, MDC and TARC. HaCaT human keratinocytes were stimulated with $\mathrm{hIFN}-\gamma(10 \mathrm{ng} / \mathrm{mL})$ to induce inflammatory chemokines (MDC and TARC). The EtOAc fraction of $P$. yedoensis bark inhibited the mRNA and protein expression of MDC and TARC in HaCaT cells. In particular, the E5 subfraction dose-dependently inhibited the mRNA expression of MDC and TARC, but the E1 fraction did not, potentially due to cytotoxicity of the $\mathrm{E} 1$ fraction on $\mathrm{HaCaT}$ cells (Fig. 3). P. yedoensis bark may therefore regulate the recruitment of Th2-type cells into lesions of $A D$ by suppressing mRNA expression and protein production of inflammatory chemokines related to AD.

IFN- $\gamma$ activates STAT, ERK, and p38 MAP kinases in several cell types (Wormald et al., 2006; Kanda et al., 2007). In particular, signaling via IFN- $\gamma$ activates the JAK-
STAT signaling pathway by coupling to its receptor. The Janus family of tyrosine kinases (Jaks) is an integral factor in IFN- $\gamma$ activated signaling cascades and regulates tyrosine phosphorylation of the STAT proteins. STAT protein translocation to the nucleus and binding to IFN- $\gamma$ activated sequences (GAS) is a crucial component of IFN- $\gamma$ signaling (Komine et al., 2005; Best et al., 2005). Also, the JAK-STAT signaling pathway is the important pathway for IFN- $\gamma$ signal transduction in HaCaT human keratinocytes. STAT1 protein levels are increased by IFN- $\gamma$ stimulation (Bito et al., 2002).

Consequently, we examined the effect of the E5 subfraction on IFN- $\gamma$ signaling in $\mathrm{HaCaT}$ cells. We confirmed that IFN- $\gamma$ induced phosphorylation and induction of STAT1 protein (Fig. 5-A). When HaCaT cells were pretreated with the E5 sub-fraction for $30 \mathrm{~min}$ addition of IFN- $\gamma$, pSTAT1 expressions increased on 0 and $30 \mathrm{~min}$, respectively. We considered this difference as an effect of E5 sub-fraction that needs to be compared with only E5 sub-fraction treatment group, excepting IFN- $\gamma$. The E5 sub-fraction of $P$. yedoensis bark inhibited this STAT1 phosphorylation at $2 \mathrm{hr}$ after IFN- $\gamma$ treatment (Fig. 5-B), and decreased STAT1 protein levels after $24 \mathrm{hr}$ (Fig. 5C). The difference between chemokine mRNA expression levels and STAT1 phosphorylation levels in a dose dependent manner may be due to exposure time of IFN- $\gamma$ (Fig. 4 and 5-B). However, further investigation is needed to determine whether the inhibition of STAT1 phosphorylation by the E5 fraction is a direct effect or occurs upstream of JAK kinase. Also, during normal JAK-STAT signaling, negative and positive feedback mechanisms exist to regulate signaling. Especially, negative feedback through the expression of suppressor of cytokine signaling proteins (SOCS) is an important role of IFN- $\gamma$ signaling (Wormald et al., 2006). Therefore, we need to explore the effect of the E5 sub fraction on SOCS protein levels.

Recently, some caffeic acid derivatives were isolated from the related Prunus species and ethyl caffeate has been isolated from P. yedoensis (Noshita et al., 2006). This compound has been reported that suppressed inflammatory mediators, iNOS, COX-2, and PGE2, through inhibition of NF-KB activation in murine macrophage or in mouse skin (Chiang et al., 2005). Also, Flavonoids, such as genistein, kaempferol, quercetin, and daidzein, have been demonstrated that they have an anti-inflammatory effect on inhibition of STAT-1 and NF$\kappa \mathrm{B}$ activations in activated macrophages (Hämäläinen et al., 2007). And we need to study more for clear effect of $P$. yedoensis because this study is limited to $\mathrm{HaCaT}$ keratinocytes, not human primary keratinocytes from $A D$ 
patient or AD-like animal model.

In this study, we have demonstrated that Prunus yedoensis bark inhibits the induction of AD-like inflammatory chemokines (MDC and TARC) via the JAK-STAT pathway associated with IFN- $\gamma$ signal transduction (Figure 6). In conclusion, the E5 sub-fraction from $P$. yedoensis bark inhibits the mRNA expression and protein production of MDC and TARC in HaCaT cells. Also, the E5 sub-fraction suppresses IFN- $\gamma$-induced STAT1 protein through loss of STAT1 phosphorylation

\section{ACKNOWLODGEMENT}

This study was supported by post-BK21 Program of the Minister of Education \& Human Resources Development, Republic of Korea.

\section{REFERENCES}

Baumer, W., Seegers, U., Braun, M., Tschernig, T. and Kietzmann, M. (2004). TARC and RANTES, but not CTACK, are induced in two models of allergic contact dermatitis. Effects of cilomilast and diflorasone diacetate on T-cell-attracting chemokines. Br. J. Dermatol. 151, 823-830.

Best, S. M., Morris, K. L., Shannon, J. G., Robertson, S. J., Mitzel, D. N., Park, G. S., Boer, E., Wolfinbarger, J. B. and Bloom, M. E. (2005). Inhibition of interferon-stimulated JAKSTAT signaling by a tick-borne flavivirus and identification of NS5 as an interferon antagonist. J. Virol. 76,12828-12839.

Bito, T., Roy, S., Sen, C. K., Shirakawa, T., Gotoh, A., Ueda, M., Ichihashi, M. and Packer, L. (2002). Flavonoids differentially regulate IFN gamma-induced ICAM-1 expression in human keratinocytes: molecular mechanisms of action. FEBS Lett. 520, 145-52.

Bonncchi, R., Sozzani, S., Stine, J. T., Luini, W., D'Amico, G., Allavena, P., Chantry, D. and Mautovani. A. (1998). Divergent effects of Interleukin-4 and Interferon- $\gamma$ on MacrophageDerived Chemokine production : An amplification circuit of polarized T helper 2 responses. Blood 92, 2668-2671.

Bordignon, V, Sinagra J. L., Trento E., Pietravalle M., Capitanio, B. and Fei, P. C. (2005). Antigen specific cytokine response in pediatric patients with atopic dermatitis. Pediatr Allergy Immunol. 16,113-120.

Chiang, Y. M, Lo, C. P., Chen, Y. P., Wang, S. Y., Yang, N. S., Kuo, Y. H., and Shyur, L. F. (2005). Ethyl caffeate suppresses NF-kappaB activation and its downstream inflammatory mediators, iNOS, COX-2, and PGE2 in vitro or in mouse skin. Br.J. Pharmacol. 146, 352-63.

Esche, C., de Benedetto, A. and Beck, L. A. (2004). Keratinocytes in atopic dermatitis: Inflammatory signals. Cur. Allergy Asthma Rep. 4, 276-284.

Fujisawa, T., Fujisawa, R., Kato, Y., Nakayama, T., Morita, A., Katsumata, H., Nishimori, H., Iguchi, K., kamiya, H., Gray, P. W., Chantry, D., Suzuki, R. and Yoshie, O. (2002). Presence of high contents of thymus and activation-regulated chemok- ine in platelets and elevated plasma levels of thymus and activation-regulated chemokine and macrophage-derived chemokine in patients with atopic dermatitis. J. Allergy Clin. Immunol. 110, 139-146.

Godiska, R., Chantry, D., Raport, C. J., Sozzanl, S., Allavena, P., Leviten, D., Mantovani, A. and Gray, P. W. (1997). Human macrophage-derived chemokine (MDC), a novel chemoattractant for monocytes, monocyte-derived dendritic cells, and natural killer cells. J. Exp. Med. 185, 1595-1604.

Grewe, M., Gyufko, K., Schöpf, E. and Krutmann, J. (1994). Expression of interferon-gamma in atopic eczema. Lancet 343, 25-26.

Hämäläinen, M., Nieminen, R., Vuorela, P., Heinonen, M., and Moilanen, E. (2007). Anti-inflammatory effects of flavonoids: genistein, kaempferol, quercetin, and daidzein inhibit STAT-1 and NF-kappaB activations, whereas flavone, isorhamnetin, naringenin, and pelargonidin inhibit only NF-kappaB activation along with their inhibitory effect on iNOS expression and NO production in activated macrophages. Mediators Inflamm. 2007, 45673.

Han, B. H. and Han, Y. N. (1978). Immunosuppressant activity of cheery bark extract. Kor. J. Pharmacog. 9, 173-175.

Han, S. K., Song, J. Y., Yun, Y. S. and Yi, S. Y. (2002). Gamma irradiation-reduced IFN- $\gamma$ expression, STAT1 signals, and cellmediated immunity. J. Biochem. Mol. Biol. 35, 583-589.

Hijnen, D., De Bruin-Weller, M., Oosting, B., Lebre C., De Jong, E., Bruijnzeel-Koomen, C. and Knol, E. (2004). Serum thymus and activation-regulated chemokine (TARC) and cutaneous $\mathrm{T}$ cell-attracting chemokine (CTACK) levels in allergic diseases: TARC and CTACK are disease-specific markers for atopic dermatitis. J. Allergy Clin. Immunol. 113, 334-40.

Horikawa, T., Nakayama, T., Hikita, I., Yamada, H., Fujisawa, R., Bito, T., Harada, S., Fukunaga, A., Chantry, D., Gray, P. W., Morita, A., Suzuki, R., Tezuka, T., Ichihashi, M. and Yoshie, O. (2002). IFN- $\gamma$-inducible expression of thymus and activation-regulated chemokine/CCL17 and macrophage-derived chemokine/CCL22 in epidermal keratinocytes and their roles in atopic dermatitis. Int. Immunol. 7, 767-773.

Ivashkiv, L. B. and Hu, X. (2004). Signaling by STATs. Arthritis Res. Ther. 6, 159-168.

Jakubzick, C., Wen, H., Matsukawa, A., Keller, M., Kunkel, S. L. and Hogaboam, C. M. (2004). Role of CCL4 ligands, CCL17 and CCL22, during schistosoma mansoni egg-induced pulmonary granuloma formation in mice. Am. J. Pathol. 165, 1211-1221.

Kakinuma, T., Nakamura, K., Wakugawa, M., Mitsui, H., Tada, Y., Saeki, H., Torii, H., Komine, M., Asahina, A. and Tamaki, K. (2002). Serum macrophage-derived chemokine (MDC) levels are closely related with the disease activity of atopic dermatitis. Clin. Exp. Immunol. 127, 270-273.

Kanda, N. and Watanabe, S. (2007). Prolactin enhances interferon-g-induced production of CXC ligand 9 (CXCL9), CXCL10, and CXCL11 in human keratinocytes. Endocrinol. 148, 2317-2325.

Komine, M. and Kakinuma, T., Kagami, S., Hanakawa, Y., Hashimoto, K., Tamaki, K. (2005). Mechanism of thymus- and activation-regulated chemokine(TARC)/CCL17 production and its modulation by roxithromycin. J. Invest. Dermatol. 125, 491- 
498.

Luster, A. D. (2001). Antichemokine immunotherapy for allergic diseases. Allergy Clin. Immunol. 1, 561-567.

Nakazato, J., Kishida, M., Kuroiwa, R., Fujiwara, J., Shimoda, M., and Shinomiya, N. (2008). Serum levels of Th2 chemokines, CCL17, CCl22, and CCl27, were the important markers of severity in infantile atopic dermatitis. Pediatr. Allergy Immunol. 1, 10.

Noshita, T., Sakaguchi, A., and Funayama, S. (2006). Isolation of ethyl caffeate from the petals of Prunus yedoensis $\mathrm{J}$. Nat. Med. 60, 266-267.

Park, E. S., Shin, M. K. and Song, H. J. (1998). A study on the antiallergic effect of cortex betula platyphyllae or cortex pruni serrulatae extract. Kor. J. Herbology. 13, 57-69.

Portengen, L., Sigsgaard, T., Omland, O, Hjort, C., Heederik, D., and Doekes, G. (2002). Low prevalence of atopy in young Danish farmers and farming students born and raised on a farm. Clin. Exp. Allergy. 32, 247-253.

Rozyk, K. J., Targowski, T., Paluchowska, E., Owczarek, W. and Kucharczyk, A. (2005). Serum thymus and activation-regulated chemokine, Macrophage-derived chemokine and eotaxin as marker of severity of atopic dermatitis. Allergy $\mathbf{6 0}$, 685-688.

Saeki, H. and Tamaki, K. (2006). Thymus and activation regulated chemokine(TARC)/CCL17 and skin diseases. J. Dermatol. Clin. Exp. Allergy 43, 75-84.

Shimada, Y., Takehara, K. and Sato, S. (2004). Both Th2 and Th1 chemokines (TARC/CCL17, MDC/CCL22, and Mig/
CXCL9) are elevated in sera from patients with atopic dermatitis. J. Dermatol. Clin. Exp. Allergy 24, 201-208.

Strobl, B., Arulampalam, V., Is'harc, H., Newman, S. J., Schlaak, J. F., Watling, D., Costa-Pereira, A. P., Schaper, F., Behrman, I., Sheehan, K. C. F., Schreiber, R. D., Horn, F., Heinrich, P .C. and Kerr, I. M. (2001). A completely foreign receptor can mediate an interferon- $\gamma$-like response. EMBO J. 20, 54315442.

Vestergaard, C., Yoneyama, H., Murai, M., Nakamura, K., Tamaki, K., Terashima, Y., Imai, T., Yoshie, O., Irimura, T., Mizutani, H. and Matsushima, K. (1999). Overproduction of Th2-specific chemokines in NC/Nga mice exhibiting atopic dermatitis-like lesions. J. Clin. Clin. Exp. Allergy 104, 10971105.

Wormald, S., Hilton, D. J., Smyth, G. K. and Speed, T. P. (2006). Proximal genomic localization of STAT1 binding and regulated transcriptional activity. BMC Genomics. 7, 254

Xiao, T., Kagami, S., Saeki, H., Sugaya, M., Kakinuma, T., Fujita, H., Yano, S., Mitsui, H., Torii, H., Komine, M., Asahina, A., Nakamura, K. and Tamaki, K. (2003). Both IL-4 and IL-13 inhibit the TNF- $\alpha$ and IFN- $\gamma$ enhanced MDC production in a human keratinocyte cell line, HaCaT cells. J. Dermatol. Sci. 31, 111-117.

Yu, B., Koga, T., Urabe, K., Moroi, Y., Maeda, S., Yanagihara, Y. and Furue, M. (2002). Differential regulation of thymus- and activation-regulated chemokine induced by IL-4, IL-13, TNFalpha and IFN-gamma in human keratinocyte and fibroblast. J. Dermatol. Sci. 30, 29-36. 